\title{
Weight reduction ameliorates inflammatory cytokines, adipocytokines and endothelial dysfunction biomarkers among Saudi patients with type 2 diabetes
}

\author{
Shehab M Abd El-Kader ${ }^{1}$, Osama H Al-Jiffri ${ }^{2}, Z_{\text {Ziyad A Neamatallah }}^{2}$, Afnan M AlKhateeb ${ }^{1}$, Saad S AlFawaz ${ }^{1}$
}

1. Department of Physical Therapy, Faculty of Applied Medical Sciences, King Abdulaziz University, Jeddah, Saudi Arabia.

2. Department of Medical Laboratory Technology, Faculty of Applied Medical Sciences, King Abdulaziz University, Jeddah, Saudi Arabia.

\begin{abstract}
Background: Type 2 diabetes mellitus (T2DM) considered as one of the cardiovascular disorders (CVD) principle risk factor as diabetes is associated with abnormal levels of endothelial function, inflammatory and adipocytokines.

Objective: The aim of this study was to measure the impact of weight reducing on inflammatory cytokines, adipocytokines and endothelial function biomarkers among obese T2DM patients.

Methods: One-hundred T2DM patients enrolled in the present study; the age range was 35-55 year. Participants shared in this study were enrolled in group (A) received diet control and aerobic exercise on treadmill, while, group (B) had no intervention for 3 months.

Results: The mean values of body mass index (BMI), tumor necrosis factor -alpha (TNF- $\alpha$ ), interleukin-6 (IL-6), leptin, inter-cellular adhesion molecule (ICAM-1), vascular cell adhesion molecule (VCAM-1), E-selectin and plasminogen activator inhibitor-1 activity (PAI-1 activity) were significantly decreased and adiponectin was increased significantly in the training group, however the results of the control group were not significant. Also, there were significant differences between both groups at the end of the study.

Conclusion: Weight reducing program modulates inflammatory cytokines, adipocytokines and endothelial function biomarkers among obese T2DM patients.

Keywords: Diabetes; endothelial dysfunction biomarkers; cytokines; adipocytokines; weight reduction.

DOI: https://dx.doi.org/10.4314/ahs.v20i3.39

Cite as: Abd El-Kader SM, Al-Jiffri OH, Neamatallah ZA, AlKhateeb AM, AlFawaz SS. Weight reduction ameliorates inflammatory cytokines, adipocytokines and endothelial dysfunction biomarkers among Saudi patients with type 2 diabetes. Afri Health Sci. 2020;20(3): 1329-1336. https:// dx.doi.org/10.4314/abs.v20i3.39
\end{abstract}

\section{Introduction}

Type 2 diabetes mellitus (T2DM) is one of the cardiovascular disorders (CVD) principle risk factor ${ }^{1-3}$, the risk of coronary artery disease is 2-4 times among patients with diabetes than non-diabetic subjects and peripheral vascular diseases risk is 10 times higher in diabetics than non-diabetics ${ }^{4-5}$. Impaired endothelial function is an early predictor of CVD $^{6-10}$.

\section{Corresponding author:}

Shehab M Abd El-Kader

Department of Physical Therapy,

Faculty of Applied Medical Sciences,

King Abdulaziz University,

P.O. Box 80324, Jeddah, 21589, Saudi Arabia.

E. mail: salmuzain@kau.edu.sa
Endothelial dysfunction means loss of endothelial ability in regulation of vascular homeostasis through control of vasoconstriction, inflammatory and thrombotic markers ${ }^{11}$. However, abnormal levels of endothelial function considered a predictor for $\mathrm{CVD}^{12}$.

Non-insulin dependent diabetes usually associated with several CVD and other body systems which are related to impaired endothelial function ${ }^{13-17}$. Increased level of systemic inflammation markers and decreased plasma adiponectin promote endothelial dysfunction which could be considered as an important pathogenic factors and potential triggers for cardiovascular disorders, insulin resistance and atherosclerosis in T2DM patients ${ }^{18-19}$. However, weight reducing program composed of diet control and exercises associated with good prognosis as it modulated atherosclerosis and inflammatory biomarkers in T2DM patients ${ }^{20-22}$. 
As there is inconclusive data regarding the impact of weight reduction upon the inflammatory cytokines, adipokines and endothelial function in obese T2DM patients. Therefore, the study aimed to determine the impact of 12 weeks of weight reducing program on inflammatory cytokines, adipokines and endothelial function in obese T2DM patients.

\section{Patients and methods}

\section{Subjects}

One-hundred T2DM subjects who were out patients of the Internal Medicine Department at King Abdul Aziz University Hospital enrolled in the present study; the age range was 35-55 year. Hypertension, musculoskeletal disorders, smoking, congestive heart failure and intake of medicine that affect the endothelial function were the exclusion criteri. Participants shared in this study were enrolled in group (A) received diet control and aerobic exercise on treadmill, while, group (B) had no intervention (figure 1).

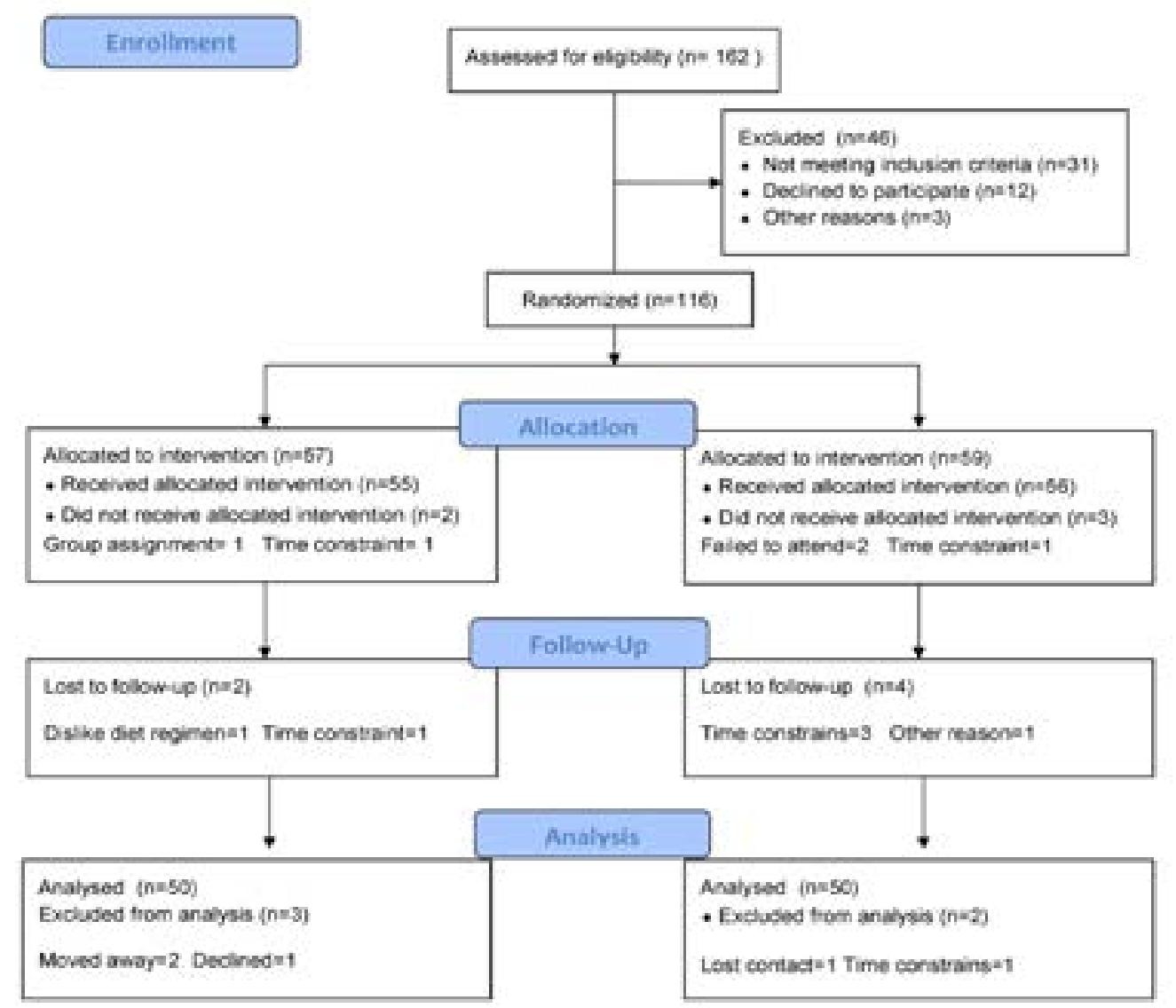

Figure 1 : Subjects screening and recruitment CONSORT diagram.

\section{Measurements}

A. Endothelial function biomarkers: Enzyme-linked immunosorbent assays (ELISAs) was used to measure inter-cellular adhesion molecule (ICAM-1) and vascular cell adhesion molecule (VCAM-1). While the level of PAI-1 activity was determined using a commercial kit (Hyphen BioMed for PAI-1, France).

B. Inflammatory cytokines and adipokines: Overnight fasting venous blood sample using ELISA was used to measure levels of Interleukin-6 (IL-6) and tu- mor necrosis factor- alpha (TNF- $\alpha$ ) "Immulite 2000" immunassay analyzer (Siemens Healthcare Diagnostics, Deerfield, USA). Also, level of adiponectin and Leptin was measured with K2EDTA in plasma sample "Hitachi 7170 Autoanalyser, Tokyo, Japan”.

\section{Procedures}

participants shared in the following groups:

1. Group (A) : Fifty type 2 diabetic patients received 3 months of aerobic treadmill exercise training conducted 
according to of American College of Sports Medicine recommendations ${ }^{23}$. Exercise program included warming -up for five minutes as range motion and stretching exercises, thirty minutes of aerobic exercise training ( $60-70 \%$ of maximum heart rate) and cooling down for ten minutes (on treadmill with low speed and without inclination). Participants received three sessions /week for three months. Also, diet control supervised by a dietician and to prescribe the balanced low caloric diet that provide 1200 Kilocalories/day for 12 weeks.

2. Group (B): Fifty type 2 diabetic patients of both sexes conducted their usual life style without intervention.

\section{Statistical analysis}

Paired " $t$ " test was used to detect significance level of the investigated parameters measured before and after the study in both groups. While, independent " $\mathrm{t}$ " test was used in comparing parameters between the two groups $(\mathrm{P}<0.05)$.

\section{Results}

One hundred patients with T2DM shared in the present study. However, basic criteria of all participants are shown in table (1). The majority of participants $(66 \%)$ were men. However, there were no significant differences related to baseline criteria between the two groups.

Table (1): Mean value of baseline characteristics of subjects for participants in both groups

\begin{tabular}{|l|c|c|c|}
\hline & Group (A) & Group (B) & Significance \\
\hline Age (year) & $41.53 \pm 5.18$ & $42.17 \pm 4.85$ & $\mathrm{P}>0.05$ \\
\hline Gender (male/female) & $34 / 16$ & $32 / 18$ & $\mathrm{P}>0.05$ \\
\hline BMI $\left(\mathrm{kg} / \mathrm{m}^{2}\right)$ & $31.16 \pm 2.89$ & $30.58 \pm 2.76$ & $\mathrm{P}>0.05$ \\
\hline Duration of diabetes (years) & $10.19 \pm 4.15$ & $9.76 \pm 3.47$ & $\mathrm{P}>0.05$ \\
\hline Waist circumference (cm) & $101.32 \pm 8.61$ & $99.74 \pm 9.39$ & $\mathrm{P}>0.05$ \\
\hline $\begin{array}{l}\text { Systolic blood } \\
\text { pressure (mmHg) }\end{array}$ & $141.75 \pm 11.13$ & $138.22 \pm 10.68$ & $\mathrm{P}>0.05$ \\
\hline $\begin{array}{l}\text { Diastolic blood } \\
\text { pressure (mmHg) }\end{array}$ & $80.14 \pm 6.51$ & $78.96 \pm 7.05$ & $\mathrm{P}>0.05$ \\
\hline HBA1c $(\%)$ & $8.26 \pm 1.71$ & $8.13 \pm 1.58$ & $\mathrm{P}>0.05$ \\
\hline
\end{tabular}

BMI= Body Mass Index; HBA1c $=$ glycosylated hemoglobin.

The mean values of BMI,TNF- $\alpha$, IL-6, Leptin, ICAM1, VCAM-1, E-selectin and PAI-1 activity were significantly decreased and adiponectin was increased signifi- cantly in the training group (table 2), however the results of the control group were not significant (table 3). Also, there were significant differences between both groups at the end of the study (table 4). 
Table (2): Mean value and significance of BMI, TNF- $\alpha$, IL-6, Leptin, Adiponectin, ICAM-1, VCAM-1, E-selectin and PAI-1 activity in group (A) before and after treatment.

\begin{tabular}{|l|c|c|c|c|}
\hline \multirow{2}{*}{} & \multicolumn{2}{|c|}{ Mean +SD } & \multirow{2}{*}{$\begin{array}{c}\text { T- } \\
\text { value }\end{array}$} & \multirow{2}{*}{ Significance } \\
\cline { 2 - 3 } & Pre & Post & \\
\hline BMI $\left(\mathrm{kg} / \mathrm{m}^{2}\right)$ & $31.16 \pm 2.89 *$ & $26.81 \pm 2.27$ & 7.86 & $\mathrm{P}<0.05$ \\
\hline TNF- $\boldsymbol{\alpha}(\mathrm{pg} / \mathrm{mL})$ & $4.62 \pm 1.44^{*}$ & $3.21 \pm 1.19$ & 6.92 & $\mathrm{P}<0.05$ \\
\hline IL-6 $(\mathrm{pg} / \mathrm{mL})$ & $2.48 \pm 0.91^{*}$ & $1.76 \pm 0.82$ & 5.87 & $\mathrm{P}<0.05$ \\
\hline Leptin $(\mathrm{Ng} / \mathrm{ml})$ & $32.11 \pm 5.23^{*}$ & $25.74 \pm 4.19$ & 7.93 & $\mathrm{P}<0.05$ \\
\hline Adiponectin $(\mu \mathrm{g} / \mathrm{mL})$ & $11.24 \pm 2.26^{*}$ & $15.16 \pm 2.73$ & 6.76 & $\mathrm{P}<0.05$ \\
\hline ICAM-1 $(\mathrm{ng} / \mathrm{ml})$ & $92.18 \pm 6.22^{*}$ & $83.14 \pm 5.71$ & 8.23 & $\mathrm{P}<0.05$ \\
\hline VCAM-1 $(\mathrm{ng} / \mathrm{ml})$ & $819.70 \pm 32.21 *$ & $743.25 \pm 27.95$ & 9.18 & $\mathrm{P}<0.05$ \\
\hline E-selectin $(\mathrm{ng} / \mathrm{ml})$ & $15.03 \pm 2.91^{*}$ & $9.13 \pm 2.34$ & 7.65 & $\mathrm{P}<0.05$ \\
\hline $\begin{array}{l}\text { PAI-1 } \\
\text { activity }(\mathrm{ng} / \mathrm{ml})\end{array}$ & $0.57 \pm 0.21^{*}$ & $0.42 \pm 0.16$ & 4.15 & $\mathrm{P}<0.05$ \\
\hline
\end{tabular}

BMI= Body Mass Index; TNF- $\alpha=$ Tumor necrosis factor -alpha; IL-6= Interleukin-6; ICAM-1 = Inter-Cellular Adhesion Molecule; VCAM-1 = Vascular Cell Adhesion Molecule; PAI-1: Ac = Plasminogen Activator Inhibitor-1 Activity; (*) indicates a significant difference, $\mathrm{P}<0.05$.

Table (3): Mean value and significance of BMI, TNF- $\alpha$, IL-6, Leptin, Adiponectin, ICAM-1, VCAM-1, E-selectin and PAI-1 activity in group (B) before and after treatment.

\begin{tabular}{|l|c|c|c|c|}
\hline \multirow{2}{*}{} & \multicolumn{2}{|c|}{ Mean +SD } & \multirow{2}{*}{ T-value } & \multirow{2}{*}{ Significance } \\
\cline { 2 - 3 } & Pre & Post & & \\
\hline BMI $\left(\mathrm{kg} / \mathrm{m}^{2}\right)$ & $30.58 \pm 2.76$ & $32.23 \pm 2.01$ & 1.19 & $\mathrm{P}>0.05$ \\
\hline TNF- $\boldsymbol{\alpha}(\mathrm{pg} / \mathrm{mL})$ & $4.13 \pm 1.54$ & $4.26 \pm 1.43$ & 0.75 & $\mathrm{P}>0.05$ \\
\hline IL-6 $(\mathrm{pg} / \mathrm{mL})$ & $2.18 \pm 0.92$ & $2.31 \pm 0.86$ & 0.58 & $\mathrm{P}>0.05$ \\
\hline Leptin $(\mathrm{Ng} / \mathrm{ml})$ & $30.74 \pm 5.11$ & $31.12 \pm 5.15$ & 1.04 & $\mathrm{P}>0.05$ \\
\hline Adiponectin $(\mu \mathrm{g} / \mathrm{mL})$ & $11.15 \pm 2.78$ & $11.03 \pm 2.75$ & 0.87 & $\mathrm{P}>0.05$ \\
\hline ICAM-1 $(\mathrm{ng} / \mathrm{ml})$ & $92.66 \pm 6.43$ & $94.05 \pm 6.14$ & 0.65 & $\mathrm{P}>0.05$ \\
\hline VCAM-1 $(\mathrm{ng} / \mathrm{ml})$ & $822.12 \pm 29.13$ & $825.10 \pm 29.21$ & 0.98 & $\mathrm{P}>0.05$ \\
\hline E-selectin $(\mathrm{ng} / \mathrm{ml})$ & $15.11 \pm 3.91$ & $15.86 \pm 3.87$ & 0.83 & $\mathrm{P}>0.05$ \\
\hline $\begin{array}{l}\text { PAI-1 } \\
\text { activity }(\mathrm{ng} / \mathrm{ml})\end{array}$ & $0.55 \pm 0.14$ & $0.57 \pm 0.16$ & 0.62 & $\mathrm{P}>0.05$ \\
\hline B. & & & \\
\hline
\end{tabular}

BMI= Body Mass Index; TNF- $\alpha=$ Tumor necrosis factor - alpha; IL- $6=$ Interleukin-6; ICAM- $1=$ Inter-Cellular Adhesion Molecule VCAM-1 = Vascular Cell Adhesion Molecule; PAI-1: Ac = Plasminogen Activator Inhibitor-1 Activity; $(*)$ indicates a significant difference, $\mathrm{P}<0.05$.

Table (4): Mean value and significance of BMI, TNF- $\alpha$, IL-6, Leptin, Adiponectin, ICAM-1, VCAM-1, E-selectin and PAI-1 activity in group (A) and group (B) at the end of the study.

\begin{tabular}{|l|c|c|c|c|}
\hline \multirow{2}{*}{} & \multicolumn{2}{|c|}{ Mean + SD } & \multirow{2}{*}{$\begin{array}{c}\text { T- } \\
\text { value }\end{array}$} & Significance \\
\cline { 2 - 3 } BMI $\left(\mathrm{kg} / \mathrm{m}^{2}\right)$ & $26.81 \pm 2.27^{*}$ & $32.23 \pm 2.01$ & 6.32 & $\mathrm{P}<0.05$ \\
\hline TNF- $\boldsymbol{\alpha}(\mathrm{pg} / \mathrm{mL})$ & $3.21 \pm 1.19^{*}$ & $4.26 \pm 1.43$ & 5.48 & $\mathrm{P}<0.05$ \\
\hline IL-6 $(\mathrm{pg} / \mathrm{mL})$ & $1.76 \pm 0.82^{*}$ & $2.31 \pm 0.86$ & 4.76 & $\mathrm{P}<0.05$ \\
\hline Leptin $(\mathrm{Ng} / \mathrm{ml})$ & $25.74 \pm 4.19^{*}$ & $31.12 \pm 5.15$ & 6.54 & $\mathrm{P}<0.05$ \\
\hline Adiponectin $(\mu \mathrm{g} / \mathrm{mL})$ & $15.16 \pm 2.73^{*}$ & $11.03 \pm 2.75$ & 5.23 & $\mathrm{P}<0.05$ \\
\hline ICAM-1 $(\mathrm{ng} / \mathrm{ml})$ & $83.14 \pm 5.71 *$ & $94.05 \pm 6.14$ & 7.41 & $\mathrm{P}<0.05$ \\
\hline VCAM-1 $(\mathrm{ng} / \mathrm{ml})$ & $743.25 \pm 27.95 *$ & $825.10 \pm 29.21$ & 8.32 & $\mathrm{P}<0.05$ \\
\hline E-selectin $(\mathrm{ng} / \mathrm{ml})$ & $9.13 \pm 2.34^{*}$ & $15.86 \pm 3.87$ & 6.19 & $\mathrm{P}<0.05$ \\
\hline $\begin{array}{l}\text { PAI-1 } \\
\text { activity }(\mathrm{ng} / \mathrm{ml})\end{array}$ & $0.42 \pm 0.16^{*}$ & $0.57 \pm 0.17$ & 3.75 & $\mathrm{P}<0.05$ \\
\hline
\end{tabular}

BMI= Body Mass Index; TNF- $\alpha=$ Tumor necrosis factor - alpha; IL-6= Interleukin-6; ICAM-1 = Inter-Cellular Adhesion Molecule; VCAM-1 = Vascular Cell Adhesion Molecule; PAI-1: Ac = Plasminogen Activator Inhibitor-1 Activity; $(*)$ indicates a significant difference, $\mathrm{P}<0.05$. 


\section{Discussion}

Vascular disorders are common among T2DM patients ${ }^{24,25}$ which are related to impaired endothelial function and systemic inflammation ${ }^{26}$. Obesity is usually associated with abnormal levels of inflammatory cytokines that induce endothelial dysfunction ${ }^{27-29}$. Level of markers of endothelial function is predictor for CVD future events ${ }^{30}$. Weight reducing program is the key for management of obesity ${ }^{31-33}$.

The principle results of the present study proved that weight loss ameliorated inflammatory cytokines (TNF- $\alpha$, IL-6 and leptin) and endothelial function markers (ICAM-1 VCAM-1, E-selectin and PAI-1 activity) as well as improvement in adiponectin in T2DM patients, these findings agreed with Cotie et al . found that four months of weight reduction program modulated endothelial function and IL- $6^{34}$. Lang et al. proved that weight reducing program for 2 months ameliorated inflammatory cytokines and abnormal blood lipid profile. ${ }^{35}$. Choo et al stated that long term weight reduction program reduced atherosclerosis and CVD risk factors ${ }^{36}$. Several studies proved that weight loss associated with improvement of inflammatory cytokines and increase level of adiponectin levels ${ }^{37-50}$.

Concerning endothelial function, results of the present study proved that weight reducing program resulted reduced levels of VCAM-1, ICAM-1 and PAI-1. These findings agreed with several studies ${ }^{51-56}$. While, Sharman and Volek found that 6-weeks of weight reducing program resulted in reduction in TNF- $\alpha$, IL- 6 and ICAM- ${ }^{57}$. Forsythe et al. stated that three months of diet control resulted in weight loss and reduced TNF- $\alpha$, IL-6, E-selectin, ICAM and plasminogen activator inhibitor-1 (PAI-1) ${ }^{58}$. Thomson et al mentioned that five months of diet control significantly reduced levels of VCAM-1, and ICAM-1 and PAI-1 among with polycystic ovary syndrome (PCOS) obese women ${ }^{59}$.

The current study has important strengths and limitations. The major strength is the supervised nature of the study. Supervising food intake and physical activity removes the need to question compliance or to rely on food and activity questionnaires. Further, all exercise sessions were supervised and adherence to the diet and activities was essentially $100 \%$. Moreover, the study was randomized; hence, we can extrapolate adherence to the general population. In the other hand, the major limitations is measuring selected cytokines (i.e. TNF- $\alpha$ and IL-6) even obesity does not only increase the cytokines selected by the authors, but also IL-5, IL-10, IL12 , IL-13 and IFN- $\gamma^{60}$, in addition small sample size in both groups may limit the possibility of generalization of the findings in the present study.

\section{Conclusion}

Weight reducing program modulates inflammatory cytokines, adipocytokines and endothelial function biomarkers among obese T2DM patients.

\section{Acknowledgment}

This project was funded by the Deanship of Scientific Research (DSR) at King Abdulaziz University, Jeddah, under grant no. (G-262-142-40). The authors, therefore, acknowledge with thanks DSR for technical and financial support.

\section{Conflict of interest}

None declared.

\section{References}

1. Tak WW, Wong, Ling S, Yu TX, Yu H. Endothelial Dysfunction: The Common Consequence in Diabetes and Hypertension. J Cardiovasc Pharmacol 2010; 55:30007 PubMed .

2. Andreassi MG, Barale R, Iozzo P, Picano E. The association of micronucleus frequency with obesity, diabetes and cardiovascular disease. Mutagenesis. 2011; 26(1):77 PubMed -83.

3.International Diabetes Federation. Diabetes: a major risk fac $\neg$ tor. http://www.cvd.idf.org (accessed 17 October 2012).

4. Karasu C. Glycoxidative stress and cardiovascular complications in experimentally-induced diabetes: effects of antioxidant treatment. Open Cardiovasc Med J. 2010; 4:240-56.

5. Ding H, Triggle CR. Endothelial cell dysfunction and the vascular complications associated with type 2 diabetes: assessing the health of the endothelium. Vasc Health Risk Manag. 2005; 1(1): 55-71.

6. Davignon J, Ganz P. Role of endothelial dysfunction in atherosclerosis. Circulation. 2004; 109(23 PubMed Suppl 1):III27-32.

7. Olson NC, Callas PW, Hanley AJ, Festa A, Haffner SM, Wagenknecht LE, Tracy RP: Circulating levels of TNF-alpha are associated with impaired glucose tolerance, increased insulin resistance, and ethnicity: the insulin resistance atherosclerosis study. J Clin Endocrinol Metab 2012, 97:1032-1040.

8. Bose KS, Gupta SK, Vyas P: Adipocytokine levels in genetically high risk for type 2 diabetes in the Indian population: a cross-sectional study. Exp Diabetes Res 2012, 2012:386524.

9. Gelaye B, Revilla L, Lopez T, Suarez L, Sanchez SE, Hevner K, Fitzpatrick AL, Williams MA: Association between insulin resistance and c-reactive protein among Peruvian adults. Diabetol Metab Syndr 2010, 2:30. 
10. Madhu SV. Endothelial Dysfunction and Diabetes. JAPI, 58: 475-476.

11. Xu J and Zou M-H. Molecular insights and therapeutic targets for diabetic endothelial dysfunction. Circulation 2009; 120: 1266-1286 PubMed .

12. Tabit C, Chung W, Hamburg N, et al. Endothelial dysfunc $\neg$ tion in diabetes mellitus: molecular mechanisms and clinical implications. Rev Endocr Metab Disord 2010; 11: 61-74.

13. Siscovick DS, Sotoodehnia N, Rea TD, Raghunathan TE, Jouven X, Lemaitre RN. Type 2 diabetes mellitus and the risk of sudden cardiac arrest in the community. Rev Endocr Metab Disord. 2010; 11(1):53-9.

14. Grauslund J, Green A, Kawasaki R, Hodgson L, Sjølie AK, Wong TY. Retinal vascular fractals and microvascular and macrovascular complications in type 1 diabetes. Ophthalmology. 2010; 117(7):1400 PubMed -5. 15. Petrofsky J, Lee S. The effects of type 2 diabetes and aging on vascular endothelial and autonomic function. Med Sci Monit. 2005; 11(6): PubMed CR247-54.

16. Okon EB, Szado T, Laher I, McManus B, van Breemen C. Augmented contractile response of vascular smooth muscle in a diabetic mouse model. J Vasc Res. 2003; 40(6):520 PubMed -30.

17. Ludmer PL, Selwyn AP, Shook TL, Wayne RR, Mudge GH, Alexander RW, Ganz P. Paradoxical vasoconstriction induced by acetylcholine in atherosclerotic coronary arteries. N Engl J Med. 1986; 315(17):1046 PubMed -51 .

18. Cao Y, Tao L, Yuan Y, Jiao X, Lau WB, Wang Y, Christopher T, Lopez B, Chan L, Goldstein B, Ma XL. Endothelial dysfunction in adiponectin deficiency and its mechanisms involved. J Mol Cell Cardiol 46: 413-419, 2009.

19. van den Oever IA, Raterman HG, Nurmohamed MT, Simsek S. Endothelial dysfunction, inflammation, and apoptosis in diabetes mellitus. Mediators Inflamm 2010: 792393, 2010.

20. Fisher G, Hyatt TC, Hunter GR, Oster RA, Desmond RA, Gower BA. Effect of diet with and without exercise training on markers of inflammation and fat distribution in overweight women. Obesity (Silver Spring), 19 (2011), pp. 1131-1136

21. Brandt C, Pedersen BK.The role of exercise-induced myokines in muscle homeostasis and the defense against chronic diseases. J Biomed Biotechnol, 2010 (2010), p. 520258 .

22. Jorge ML, de Oliveira VN, Resende NM, Paraiso LF, Calixto A, Diniz AL. The effects of aerobic, resistance, and combined exercise on metabolic control, inflammatory markers, adipocytokines, and muscle insulin signa- ling in patients with type 2 diabetes mellitus. Metabolism, 60 (2011), pp. 1244-1252.

23.American College of Sports Medicine .Guidelines for graded exercise testing and exercise prescription, Lea \& Febiger, Philadelphia, 2005.

24. Avogaro A, Albiero M, Menegazzo L, de Kreutzenberg S, Fadini GP (2011) Endothelial dysfunction in diabetes: the role of reparatory mechanisms. Diabetes Care 34 Suppl 2: S285-290.

25. Ding H, Triggle CR (2010) Endothelial dysfunction in diabetes: multiple targets for treatment. Pflugers Arch 459: 977-994.

26. Zhang H, Zhang J, Ungvari Z, Zhang C. Resveratrol improves endothelial function: role of $\mathrm{TNF} \alpha$ and vascular oxidative stress. Arterioscler Thromb Vasc Biol 29: 1164-1171, 2009.

27. Teng KT, Chang CY, Chang LF, Nesaretnam K. Modulation of obesity-induced inflammation by dietary fats: mechanisms and clinical evidence. Nutr J. 2014 Jan 29; $13: 12$.

28. Haffner SM. The metabolic syndrome: inflammation, diabetes mellitus, and cardiovascular disease. $\mathrm{Am} \mathrm{J}$ Cardiol. 2006; 97(2):3A-11A.

29. Zhang C. The role of inflammatory cytokines in endothelial dysfunction. Basic Res Cardiol. 2008; 103(5):398-406.

30. Widlansky ME, Gokce N, Keaney JF Jr, Vita JA. The clinical implications of endothelial function. $J A m$ Coll Cardiol. 2003; 42(7): 1149-1160.

31. Balagopal P, George D, Patton N, Yarandi H, Roberts WL, et al. (2005) Lifestyle-only intervention attenuates the inflammatory state associated with obesity: a randomized controlled study in adolescents. $J$ Pediatr 146: 342-348.

32. Roth CL, Kratz M, Ralston MM, Reinehr T (2011) Changes in adipose-derived inflammatory cytokines and chemokines after successful lifestyle intervention in obese children. Metabolism 60: 445-452.

33. Roberts CK, Chen AK, Barnard RJ (2007) Effect of a short-term diet and exercise intervention in youth on atherosclerotic risk factors. Atherosclerosis. 191: 98-106.

34. Cotie LM, Josse AR, Phillips SM, MacDonald MJ. Endothelial function increases after a 16-week diet and exercise intervention in overweight and obese young women. Biomed Res Int. 2014; 2014:327395.

35. Lang HF, Chou CY, Sheu WH, Lin JY. Weight loss increased serum adiponectin but decreased lipid levels in obese subjects whose body mass index was lower than $30 \mathrm{~kg} / \mathrm{m}^{2}$. Nutr Res. 2011 May;31(5):378-86.

36. Choo J, Lee J, Cho JH, Burke LE, Sekikawa A, Jae SY. Effects of weight management by exercise modes 
on markers of subclinical atherosclerosis and cardiometabolic profile among women with abdominal obesity: a randomized controlled trial. BMC Cardiovasc Disord. 2014 Jul 10; 14:82.

37. Madsen EL, Rissanen A, Bruun JM, et al. Weight loss larger than $10 \%$ is needed for general improvement of levels of circulating adiponectin and markers of inflammation in obese subjects: a 3-year weight loss study. Eur J Endocrinol. 2008; 158(2):179-187.

38. Esposito K, Pontillo A, Di Palo C, Giugliano G, Masella M, Marfella R, et al. Effect of weight loss and lifestyle changes on vascular inflammatory markers in obese women: a randomized trial. JAMA 2003; 289:1799-804 PubMed .

39. Ryan AS, Nicklas BJ, Berman DM, Elahi D. Adiponectin levels do not change with moderate dietary induced weight loss and exercise in obese postmenopausal women. Int J Obes Relat Metab Disord 2003; 27:1066-71. 40. Nicklas BJ, You T, Pahor M. Behavioral treatments for chronic systemic inflammation: effects of dietary weight loss and exercise training. CMAJ 2005; 172:1199209 PubMed .

41. Loria-Kohen V, Fernández-Fernández C, Bermejo LM, Morencos E, Romero-Moraleda B, Gómez-Candela C. Effect of different exercise modalities plus a hypocaloric diet on inflammation markers in overweight patients: a randomised trial. Clin Nutr. 2013 Aug; 32(4):511-8.

42. Sheu WH, Chang TM, Lee WJ, Ou HC, Wu CM, Tseng LN, Lang HF, Wu CS, Wan CJ, Lee IT. Effect of weight loss on proinflammatory state of mononuclear cells in obese women. Obesity (Silver Spring). 2008 May; 16(5):1033-8.

43. Rokling-Andersen MH, Reseland JE, Veierød MB, Anderssen SA, Jacobs DR Jr, Urdal P, Jansson JO, Drevon CA. Effects of long-term exercise and diet intervention on plasma adipokine concentrations. Am J Clin Nutr. 2007 Nov; 86(5):1293-301.

44. Garanty-Bogacka B. , Rać M., Syrenicz M., Gębala A., Walczak M. and Syrenicz A. Changes in Serum Adipocytokines and Inflammatory Biomarkers Following One-Year of Exercise Training in Obese Adolescents. J Diabetes Metab 2012, 3:7: 212-217.

45. Habib P, Scrocco JD, Terek M, Vanek V, Mikolich JR. Effects of bariatric surgery on inflammatory, functional and structural markers of coronary atherosclerosis. Am J Cardiol. 2009; 104:1251-1255 PubMed .

46. Sledzinski T, Sledzinski M, Smolenski RT, Swierczynski J. Increased serum nitric oxide concentration after bariatric surgery--a potential mechanism for cardiovascular benefit. Obes Surg. 2010; 20:204-210 PubMed . 47. Moschen AR, Molnar C, Geiger S, Graziadei I,
Ebenbichler CF, Weiss H, Kaser S, Kaser A, Tilg H. Anti-inflammatory effects of excessive weight loss: Potent suppression of adipose interleukin 6 and tumour necrosis factor alpha expression. Gut. 2010; 59:1259_ 1264 PubMed .

48. Laimer M, Ebenbichler CF, Kaser S, Sandhofer A, Weiss H, Nehoda H, Aigner F, Patsch JR. Markers of chronic inflammation and obesity: A prospective study on the reversibility of this association in middle-aged women undergoing weight loss by surgical intervention. Int J Obes Relat Metab Disord. 2002; 26:659-662.

49. Garcia de la Torre N, Rubio MA, Bordiu E, Cabrerizo L, Aparicio E, Hernandez C, Sanchez- Pernaute A, Diez-Valladares L, Torres AJ, Puente M, Charro AL. Effects of weight loss after bariatric surgery for morbid obesity on vascular endothelial growth factor-a, adipocytokines, and insulin. J Clin Endocrinol Metab. 2008; 93:4276-4281.

50. Marfella R, Esposito K, Siniscalchi M, et al. Effect of weight loss on cardiac synchronization and proinflammatory cytokines in premenopausal obese women. Diabetes Care 2004; 27:47-52 PubMed .

51. Hamdy O, Ledbury S, Mullooly C, Jarema C, Porter S, Ovalle K, Moussa A, Caselli A, Caballero AE, Economides PA et al. Lifestyle modification improves endothelial function in obese subjects with the insulin resistance syndrome. Diabetes Care 2003; 26:2119-2125 PubMed .

52. Murakami T, Horigome H, Tanaka K, Nakata Y, Ohkawara K, Katayama Y, Matsui A. Impact of weight reduction on production of platelet-derived microparticles and fibrinolytic parameters in obesity. Thromb Res 2007; 119:45-53 PubMed.

53. Meckling KA, O'Sullivan C, Saari D. Comparison of a low-fat diet to a low-carbohydrate diet on weight loss, body composition, and risk factors for diabetes and cardiovascular disease in free-living, overweight men and women. J Clin Endocrinol Metab 2004; 89:2717-2723.

54. Keogh JB, Brinkworth GD, Noakes M, Belobrajdic DP, Buckley JD, Clifton PM. Effects of weight loss from a very-low-carbohydrate diet on endothelial function and markers of cardiovascular disease risk in subjects with abdominal obesity. Am J Clin Nutr 2008; 87:567-576 PubMed .

55. Wegge JK, Roberts CK, Ngo TH, Barnard RJ. Effect of diet and exercise intervention on inflammatory and adhesion molecules in postmenopausal women on hormone replacement therapy and at risk for coronary artery disease. Metabolism 2004; 53:377-381 PubMed .

56. Rector RS, Turk JR, Sun GY, Guilford BL, Toedebusch BW, McClanahan MW, Thomas TR. Shortterm lifestyle modification alters circulating biomarkers 
of endothelial health in sedentary, overweight adults. Appl Physiol Nutr Metab 2006; 31:512-517.

57. Sharman MJ, Volek JS: Weight loss leads to reductions in inflammatory biomarkers after a very-low-carbohydrate diet and a low-fat diet in overweight men. Clin Sci (Lond) 2004, 107:365-369 PubMed .

58. Forsythe CE, Phinney SD, Fernandez ML, Quann EE, Wood RJ, Bibus DM, Kraemer WJ, Feinman RD, Volek JS: Comparison of low fat and low carbohydrate diets on circulating fatty acid composition and markers of inflammation. Lipids 2008, 43:65-77 PubMed .
59. Thomson RL, Brinkworth GD, Noakes M, Clifton PM, Norman RJ, Buckley JD. The effect of diet and exercise on markers of endothelial function in overweight and obese women with polycystic ovary syndrome. Hum Reprod. 2012; 27(7):2169 PubMed -76.

60. Schmidt FM, Weschenfelder J, Sander C, Minkwitz J, Thormann J, Chittka T, Mergl R, Kirkby KC, Faßhauer M, Stumvoll M, Holdt LM, Teupser D, Hegerl U, Himmerich H.Inflammatory Cytokines in General and Central Obesity and Modulating Effects of Physical Activity. PLoS One. 2015;10(3): PubMed e0121971. 